\title{
Effect of Bromocriptine on Anthropometric, Metabolic and Inflammatory Parameters in Obese Women
}

Ayad Ali Hussein

Clinical Pharmacy and Therapeutic Department,Faculty of Pharmacy, University of Kufa, Najaf Governorate, Iraq

\section{$\underline{\text { Abstract : }}$}

Background: Obesity associated with high risk of cardiovascular disease and diabetes due to impairment in glucose and lipid metabolism as well as low grade inflammatory response. Hypothalamic hypodopaminergic state is observed in obese subject. Accordingly, treatment with Bromocriptine, a centrally acting dopamine D2-receptor agonist, was reported to regulate food intake and improve insulin sensitive and glucose tolerance in obese subject.

Aim: The objective of this study is to investigate the potential effect of bromocriptine on body weight and metabolic parameter as well as the inflammatory response in obese women.

Method: Out of 46 women enrolled in the study, 12 women did not complete study. The remaining 34 patients divided into two groups Group I: Control group $(\mathrm{N}=16)$, this group advised only for dietary therapy plus life style modifications. Group II: Bromocriptine group $(\mathrm{N}=18)$; The women of this group given $2.5 \mathrm{mg}$ bromocriptine at morning once daily for 12 weeks in addition dietary therapy plus life style modifications as in group I.Body weight (WT) and body mass index (BMI) and Fasting blood glucose level (FBG), Lipid profile [total cholesterol (TC), triglyceride (TG), high-density lipoprotein (HDL-C), low-density lipoprotein (LDL-C)] and inflammatory markers high sensitive C-reactive protein (hsCRP) and tumor necrosis factor alpha $(\mathrm{TNF}-\alpha)$ were measured before and after 12 weeks of the treatment.

Results:Compared to baseline value, WT and BMI decreased significantly on both bromocriptine and control group but the change in WT and BMI did not significantly different between the two groups. Bromocriptine treatment for 12 weeks significantly $(\mathrm{P}<0.05)$ improve FBG, TG and LDL-C compared to the base line value and alsothe reductions in FBG, TG and LDL-C were significantly $(\mathrm{P}<0.05)$ higher than that observed in 
Thi-Qar Medical Journal (TQMJ): Vol.(16), No.(2), 2018

Web Site: https://jmed.utq.edu.iq

ISSN (Print):1992-92 18, ISSN(Online):1992-92 18

Email:utjmed@utq.edu.iq

DOI: https://doi.org/10.32792/utq/utjmed/16/2/1/

control group. Both hsCRP and TNF- $\alpha$ significantly $(\mathrm{P}<0.05)$ reduced by bromocriptine after 12 weeks compared to the baseline and the decrease in hsCRP was significantly different from that in the control group.

Conclusion: Bromocriptine effectively reduced fasting glucose, improved lipid profile and suppressed low grade inflammatory response on obese women.

Recommendation: Further clinical study on large sample size and longer duration is recommended to explore bromocriptine effects on health obese subject.

\section{Introduction}

Obesity defined as the excess accumulation of body fat or adiposity which leads to many health comorbidities especially for central obesity[1].According to latest WHO report, prevalence growing dramatically to reach to $13 \%$ worldwide [2]. Obesity lead to increased risk of metabolic linked disease such as cardiovascular diseases, diabetes, osteoarthritis, cancer and fatty liver disease [3].Impaired in glycemic control and insulin resistance are commonly associated with obese subject therefore the increasing prevalence of diabetes directly related to that of obesity over the past 30 years. Accordingly, the conditions have become known as twin epidemics [4]. Also, disturbances in lipid metabolism are very commonly seen in obese persons and characterized by elevation in triglyceride level mainly due to increase production of hepatic very lowdensity lipoprotein (VLDL) [5]. Dyslipidemia in obese subject are driven by insulin resistance and low grade inflammatory response evoked by macrophage infiltrating in adipose tissue [6, 7]. These macrophages of adipose tissue are predominantly M1

phenotype which produce inflammatory cytokines such as TNF- $\alpha$, IL-6 and IL1B [8]. These pro-inflammatory cytokineswill impair insulin signaling and activates lipolysis, thus increasing level of free fatty acid (FFA), which will be used as substrate for hepatic TG synthesis. Additionally, this high level of the pro-inflammatory cytokinesinhibits clearance of TG rich lipoprotein via suppressing lipoprotein lipase. Thus,obesity associated low grade inflammatory repose will increase the production and decrease the clearance of triglyceride rich lipoproteins, which both will finally contribute to the elevation in TG level $[7,9]$. Dopamine regulates our capacity 
Web Site: https://jmed.utq.edu.iq

ISSN (Print):1992-92 18, ISSN(Online):1992-92 18

DOI: https://doi.org/10.32792/utq/utjmed/16/2/1/

\section{Email:utjmed@utq.edu.iq}

to feel pleasure and food intake by modulating food reward via the mesolimbic circuitry of the brain [10]. D2 receptor availability in the striatum modulates eating behavioral patterns [11]. In addition to that, dopaminergic neurotransmission notably involved in both glucose and lipid metabolism [12]. Interestingly, obese subject has hypodopaminergic state as evident by lower D2 \& D3 striatal dopamine receptor compared to normal subjects [13]. Accordingly, treatment with Bromocriptine, a centrally acting dopamine D2-receptor agonist, was reported to regulate food intake and improve insulin sensitive and glucose tolerance in obese subject $[14,15]$. In this study, we aimed to further investigate the potential effect of bromocriptine on body weight and metabolic parameter as well as the associated inflammatory response in obese women.

\section{Subjects and Methods}

\section{Study participants and protocol}

The participants of study were outpatient obese women who visited a primary care clinic in $\mathrm{Al}$ najaf governorate. The women are interviewed by questionnaire which covered the main aspects of the medical history and physical examinations by physician. All the women were in good health and we excluded the women
withCVD, diabetes, inflammatory diseases, hepatic or renal impairment, hyperprolactinemia, Psychiatric disease, pregnancy and breast feeding. Out of 95 screened women, 46 women met the eligibility criteria and enrolled in this study. All women are informed about the study and their verbal agreements are obtained before they are included in the study. The study is approved by Scientific Committee of Clinical Pharmacy and Therapeutic Department of Faculty of Pharmacy Kufa University. Out of 46 women, twelve women did not complete study due to many reasons, loss to follow up (5), developed adverse effects (4) and noncompliance (3). The remaining 34 patients divided into two groups Group I: Control group $(\mathrm{N}=16)$, this group advised only for dietary therapy plus life style modifications. Group II: Bromocriptine group ( $\mathrm{N}=18)$; The women of this group given2.5mgbromocriptine at morningonce daily for 12 weeks in addition dietary therapy plus life style modifications as in group I.

\section{Biochemical measurements}

About $10 \mathrm{ml}$ of blood sample were collected from all subject after $12 \mathrm{hr}$ fasting at zero time and after 12 weeks of treatment. Serum was obtained by centrifugation at $3000 \mathrm{rpm}$ for $10 \mathrm{~min}$. fasting blood glucose level was measured by readymade kit. Serum TC, 
Web Site: https://jmed.utq.edu.iq

ISSN (Print):1992-92 18, ISSN(Online):1992-92 18

DOI: https://doi.org/10.32792/utq/utjmed/16/2/1/

TG and HDL-C levels were determined according to kit obtained from Bio Merieux, France. Plasma LDL-C was calculated by using this formula: [LDL$\mathrm{C}=$ Total cholesterol $-(\mathrm{TG} / 5)-(\mathrm{HDL}-$ C)] and the results were expressed in $\mathrm{mg} / \mathrm{dl}$. High-sensitive $\mathrm{C}$ - reactive protein (hsCRP) and TNF-alpha were measured by enzyme-linked immunosorbent assay (ELISA) by kit for each of them provided by Demeditec Diagnostics Gmbh, Germany.
Email:utjmed@utq.edu.iq

\section{Statistical analysis}

Paired Student's t test was used to compare values within each group over the treatment periods while independent sample $\mathrm{t}$ tests were used to compare between bromocriptine and control group. Data are presented as mean \pm Standard error mean (SEM). $\mathrm{P}<0.05$ was considered statistically significant using a two-tailed test. Statistical analysis of data was performed using the Statistical Package for Social Sciences software version 21.0 (SPSS, Chicago,

IL)

\section{Results}

\section{Baseline characters}

Thirty-four women completed the study protocol. All those women were obese with BMI range from 30-42 and with age between 23-62 years old. The baseline characters of women were not different significantly between the two groups as shown in table 1 .

Table 1. Baseline characters of the participant women, Data expressed mean \pm SEM.

\begin{tabular}{|c|c|c|}
\hline Parameters & $\begin{array}{c}\text { Control } \\
(\mathbf{n = 1 6})\end{array}$ & $\begin{array}{c}\text { Bromocriptine } \\
(\mathbf{n = 1 8})\end{array}$ \\
\hline Age & $42.7 \pm 3.5$ & $43.9 \pm 2.3$ \\
\hline WT & $98.1 \pm 2.33$ & $101.6 \pm 4.0$ \\
\hline Height & $1.65 \pm 0.02$ & $1.67 \pm 0.024$ \\
\hline BMI & $35.9 \pm 0.77$ & $36.3 \pm 1.01$ \\
\hline FBG & $107.1 \pm 1.8$ & $106.3 \pm 1.6$ \\
\hline TC & $184.6 \pm 5.7$ & $187.9 \pm 8.1$ \\
\hline TG & $190.4 \pm 12.4$ & $188.7 \pm 10.4$ \\
\hline HDL-C & $45.55 \pm 3.3$ & $47.9 \pm 3.2$ \\
\hline LDL-C & $100.1 \pm 5.67$ & $102.1 \pm 7.8$ \\
\hline hsCRP & $3.5 \pm 0.56$ & $4.10 \pm 0.5$ \\
\hline TNF-alpha & $46.33 \pm 6.1$ & $49.5 \pm 5.3$ \\
\hline
\end{tabular}


Thi-Qar Medical Journal (TQMJ): Vol.(16), No.(2), 2018

Web Site: https://jmed.utq.edu.iq

ISSN (Print):1992-92 18, ISSN(Online):1992-92 18

Email:utjmed@utq.edu.iq

DOI: https://doi.org/10.32792/utq/utjmed/16/2/1/

\section{Effect bromocriptine on anthropometric parameters}

Both groups revealed a significant decrease in the WT and BMI after 12 weeks $(\mathrm{P}<0.05)$ compared with baseline values. But the reduction in WT and BMI in bromocriptine group were not significantly $(\mathrm{P}>0.05)$ different from that in control group (Table 2$)$.

Table 2. Effect of bromocriptine on the body weight (WT) and body mass index (BMI) after 12 weekstreatment and the change from baseline. Data expressed as mean \pm SEM

\begin{tabular}{|c|c|c|c|}
\hline \multicolumn{2}{|c|}{ Parameters } & Control & Bromocriptine \\
\hline \multirow{4}{*}{ WT } & Baseline & $98.21 \pm 2.33$ & $101.6 \pm 4.0$ \\
\cline { 2 - 4 } & 12 weeks & $95.1 \pm 1.91^{\mathrm{a}}$ & $97.0 \pm 3.22^{\mathrm{a}}$ \\
\cline { 2 - 4 } & Change & $3.10 \pm 1.2$ & $4.7 \pm 1.3$ \\
\hline \multirow{3}{*}{ BMI } & Baseline & $35.9 \pm 0.77$ & $36.3 \pm 1.01$ \\
\cline { 2 - 4 } & 12 weeks & $34.8 \pm 0.94^{\mathrm{a}}$ & $35.3 \pm 0.85^{\mathrm{a}}$ \\
\cline { 2 - 4 } & Change & $-1.1 \pm 0.49$ & $-1.01 \pm 0.45$ \\
\hline
\end{tabular}

${ }^{\mathrm{a}} \mathrm{p}<0.05$ for the parameters after 12 weeks treatment compared to the baseline.

\section{Effect of bromocriptine on metabolic parameters (FBG and lipid profile)}

At the end of study, FBG level significantly $(\mathrm{P}<0.05)$ reduced in bromocriptine group but not $(\mathrm{P}>0.05)$ in control group compared to the baseline value. The reduction in FBG level were significantly $(\mathrm{P}<0.05)$ higher in bromocriptine group higher than that in the control group. After 12 week of bromocriptine administration, TG and LDL-C significantly $(\mathrm{P}<0.05)$ decreased while TC and HDL-C did not decrease significantly $(\mathrm{P}>0.05)$ compared to initial value. In control group, all lipid parameters did not change significantly $(\mathrm{P}>0.05)$ over the treatment period. Interestingly bromocriptine caused significant $(\mathrm{P}<0.05)$ reductions in both TG and LDL-C level compared to the change occurred in control group. 
Thi-Qar Medical Journal (TQMJ): Vol.(16), No.(2), 2018

Web Site: $\underline{\text { https://jmed.utq.edu.iq }}$

ISSN (Print):1992-92 18, ISSN(Online):1992-92 18

Email:utjmed@utq.edu.iq

DOI: https://doi.org/10.32792/utq/utjmed/16/2/1/

Table 3. Effect of bromocriptine on fasting glucose level and lipid profile in obese women after 12 weeks treatment and the change from baseline. Data expressed as mean \pm SEM.

\begin{tabular}{|c|c|c|c|}
\hline \multicolumn{2}{|c|}{ Parameters } & \multirow{2}{*}{$\begin{array}{l}\text { Control } \\
\qquad 107.1 \pm 1.8\end{array}$} & \multirow{2}{*}{$\begin{array}{l}\text { Bromocriptine } \\
\qquad 106.3 \pm 1.6\end{array}$} \\
\hline FB & Baseline & & \\
\hline G & 12 weeks & $102.1 \pm 2.7$ & $91.2 \pm 2.4^{\mathrm{a}}$ \\
\hline & Change & $5.0 \pm 3.12$ & $15.1 \pm 2.7^{b}$ \\
\hline \multirow[t]{3}{*}{ TC } & Baseline & $184.63 \pm 5.7$ & $187.9 \pm 8.1$ \\
\hline & 12 weeks & $182.12 \pm 6.1$ & $180.0 \pm 6.76$ \\
\hline & Change & $-2.54 \pm 4.2$ & $-8.0 \pm 4.51$ \\
\hline \multirow[t]{3}{*}{ TG } & Baseline & $190.39 \pm 12.4$ & $188.7 \pm 10.4$ \\
\hline & 12 weeks & $184.1 \pm 10.21$ & $169.0 \pm 8.3^{\mathrm{a}}$ \\
\hline & Change & $-6.5 \pm 3.51$ & $-19.5 \pm 3.64^{b}$ \\
\hline \multirow{3}{*}{$\begin{array}{l}\text { HD } \\
\text { L-C }\end{array}$} & Baseline & $45.55 \pm 3.3$ & $47.9 \pm 3.2$ \\
\hline & 12 weeks & $46.61 \pm 2.4$ & $53.3 \pm 3.6$ \\
\hline & Change & $1.1 \pm 2.3$ & $4.6 \pm 2.5$ \\
\hline \multirow{3}{*}{$\begin{array}{l}\text { LD } \\
\text { L-C }\end{array}$} & Baseline & $100.1 \pm 5.67$ & $102.1 \pm 7.8$ \\
\hline & 12 weeks & $98.0 \pm 7.4$ & $92.5 \pm 7.5^{\mathrm{a}}$ \\
\hline & Change & $-2.1 \pm 3.61$ & $-9.6 \pm 4.4^{b}$ \\
\hline
\end{tabular}

${ }^{a} \mathrm{p}<0.05$ for the parameters after 12 weeks treatment compared to the baseline. ${ }^{b} \mathrm{p}<0.05$ for change induced by bromocriptine compared to that in control group.

\section{Effect of bromocriptine on inflammatory parameters}

After 12 weeks of therapy, bromocriptine markedly $(\mathrm{P}<0.05)$ lowered hsCRP and TNF- $\alpha$ as compared to initial value while these parameters did not significantly $(\mathrm{P}>0.05)$ change over the period of treatment in the control group. Importantly, the reduction hsCRP was significantly $(\mathrm{P}<0.05)$ higher in bromocriptine group than that in control group. Although there was tendency in lowering TNF- $\alpha$ level by bromocriptine treatment, this reduction was not statistically significant $(\mathrm{P}>0.05)$ in comparison with the change in the control group. 
Thi-Qar Medical Journal (TQMJ): Vol.(16), No.(2), 2018

Web Site: $\underline{\text { https://jmed.utq.edu.iq }}$

ISSN (Print):1992-92 18, ISSN(Online):1992-92 18

Email:utjmed@utq.edu.iq

DOI: https://doi.org/10.32792/utq/utjmed/16/2/1/

Table 4. Effect of bromocriptine on high sensitive $C$ - reactive protein (hsCRP) and tumor necrosis factor alpha (TNF- $\alpha$ ) after 12 weeks period and the change from baseline. Data expressed as mean \pm SEM.

\begin{tabular}{|c|c|c|c|}
\hline \multicolumn{2}{|c|}{ Parameters } & Control & Bromocriptine \\
\hline \multirow{3}{*}{ hsCRP } & Baseline & $3.5 \pm 0.56$ & $4.10 \pm 0.5$ \\
\cline { 2 - 4 } & 12 weeks & $3.7 \pm 0.54$ & $2.74 \pm 0.4^{\mathrm{a}}$ \\
\cline { 2 - 4 } & Change & $0.2 \pm 0.55$ & $-1.33 \pm 0.4^{\mathrm{b}}$ \\
\hline \multirow{3}{*}{ TNF- $\boldsymbol{\alpha}$} & Baseline & $46.33 \pm 6.1$ & $49.5 \pm 5.3$ \\
\cline { 2 - 4 } & 12 weeks & $44.4 \pm 5.8 .2$ & $39.43 \pm 3.6^{\mathrm{a}}$ \\
\cline { 2 - 4 } & Change & $-1.93 \pm 2.97$ & $-9.9 \pm 2.2$ \\
\hline
\end{tabular}

${ }^{a} \mathrm{p}<0.05$ for the parameters after 12 weeks treatment compared to the baseline. ${ }^{b} \mathrm{p}<0.05$ for change induced by bromocriptine compared to that in control group.

\section{Discussion}

\section{Effect of bromocriptine on body weight and body mass index}

In the present study, although bromocriptine significantly reduced WT and BMI over 12 weeks, it did not lower WT and BMI more remarkable than dietary advice and life style modification alone in the control group. There are many controversies in the effect ofcentral dopamine agonist on the WT and BMI. Some studies showed significant weight loss with dopamine agonist therapy [16, 17] while other studies failed to demonstrate significant weight loss.[14, 18]. The discrepancy in the effect of dopamine agonist on WT and BMI may be attributed to the differences in the treatment duration, dietary and life-style modifications and/or different patient characters. The duration of the study is main limitation factor to show significant effect of bromocriptine on body weight because it regulates eating behaviors via acting on central dopaminergic neuron to modulate food reward and pleasure and hence need time to control of complex processes driving feeding behavior [15].

\section{Effect of bromocriptine on fasting glucose level and lipid profile}

The data of present study revealed that 12-week therapy of bromocriptine resulted in remarkable improvement in fasting glucose level of obese women. This beneficial effect of Bromocriptine on glycemic control is well documented because bromocriptine in timed released formulation marketed as (Cycloset) has 
Thi-Qar Medical Journal (TQMJ): Vol.(16), No.(2), 2018

Web Site: https://jmed.utq.edu.iq

ISSN (Print):1992-92 18, ISSN(Online):1992-92 18

DOI: https://doi.org/10.32792/utq/utjmed/16/2/1/
Email:utjmed@utq.edu.iq been approved by FDA as antidiabetic drugs. In our study, we used conventional bromocriptine formulations (Parlodel) which is different in bioavailability and peak levels from the approved one. However, previous study demonstrated similar improvement in fasting glucose and diurnal glucose level by using conventional tablet of bromocriptine $2.5 \mathrm{mg}$ BID in obese women [14]. Also,Aminorroaya et al, showed significant reduction in FBG after 12week treatment of $2.5 \mathrm{mg}$ bromocriptine in obese diabetic patients [18]. Interestingly, in recent study, significant improvement in insulin sensitivity and glucose have been demonstrated in obese subject after 2-week therapy of $2.5 \mathrm{mg}$ once daily dose of bromocriptine [19]. The beneficial effect on glycemic control by bromocriptine attributed to activation of D2 -receptor in hypothalamus that exerting suppressing effect on noradrenergicserotonergic activities which resulting in inhibiting hepatic glucose production and therefore improving glucose level [20].

The present study also showed that therapy with bromocriptine notably improved lipid profile in obese subjected as evident by significant lowering of TG and LCL-C level compared to the baseline and to the control group. Consistently, 8-week bromocriptine treatments significantly lowered free fatty acid, TG and TC in obese non-diabetic women [21]. Additionally,(Cincotta et al 1999) reported substantial improvement in serum lipid profile after 6 moth treatments with bromocriptine in diabetic patients [22]. This lipid lowering effect of bromocriptine also can explained by resettingthe abnormally elevated hypothalamic noradrenergic tone thus inhibiting lipolysis, decrease FFA and TG level [20].

\section{Effect of bromocriptine on inflammatory parameters}

Low grade metabolic inflammation is a hall mark characterizing obesity and has been considered as driving force for insulin resistance, metabolic syndrome and T2D [23]. Numerous studies have demonstrated causal association of inflammatory markers like (hsCRP\& TNF- $\alpha$ ) with the development of insulin resistance, dyslipidemia and diabetes and CVD [8, 24, 25]. The data from our study demonstrated that administration of central dopamine agonist, bromocriptine, effectively suppressed the metabolic inflammatory response associated with obesity as evident by significant lowering of acute inflammatory protein namely, hsCRP and the proinflammatory cytokine namely, TNF- $\alpha$ after 12-week treatment. The inhibitory effect of dopamine agonist bromocriptine and cabergoline on low grade systemic inflammatory response have been previously reported by (Krysiak et al 2014) in two studies [26, 27].We mentioned that obesity associated 
Thi-Qar Medical Journal (TQMJ): Vol.(16), No.(2), 2018

Web Site: $\underline{\text { https://jmed.utq.edu.iq }}$ ISSN (Print):1992-92 18, ISSN(Online):1992-92 18

DOI: https://doi.org/10.32792/utq/utjmed/16/2/1/ proinflammatory cytokine (TNF and IL-

1) will enhance $\mathrm{TG}$ production via promoting lipolysis and decrease TG clearance via suppressing lipoprotein lipase [7, 9]. Additionally, chronic over nutrition will induce metabolic inflammatory response in hypothalamusleading to a spectrum of metabolic syndrome disorders such as obesity, insulin resistance, and diabetes [28]. Interestingly, suppression of inflammation has been shown as an effective therapeutic strategy against over nutrition related glucose disorders. Anti-

\section{Email:utjmed@utq.edu.iq}

inflammatory medications such as aspirin [29] and salsalate [30] have proven effective against T2D and related lipid disorders in clinical trials. Therefore; the anti-inflammatory effects of bromocriptine might further contribute to its beneficial effect on glucose and lipid and metabolism. Collectivelyfrom data of this study, we can conclude that bromocriptine effectively reduced fasting glucose, improved lipid profile and suppressed low grade inflammatory response in obese women.

\section{References}

1. Tchernof A, Despres JP. Pathophysiology of human visceral obesity: an update. Physiol Rev 2013;93(1):359-404.

2. WHO "Obesity and overweight". World Health Organization. Fact sheet updated 2016

3. Castro AB, Kolka CK, Kim PS, and Bergman RN. Obesity, insulin resistance and comorbidities Mechanisms of association. Arq Bras Endocrinol Metabol. 2014; 58(6): 600-609.

4. Khaodhiar L, Cummings S, Apovian CM. Treating diabetes and prediabetes by focusing on obesity management. Curr Diab Rep. 2009;9(5):348-54.

5. Klop, B., J.W. Elte, and M.C. Cabezas, Dyslipidemia in obesity: mechanisms and potential targets. Nutrients, 2013. 5(4):1218-40.

6. Bays, H.E., et al., Obesity, adiposity, and dyslipidemia: a consensus statement from the National Lipid Association. J ClinLipidol, 2013. 7(4): 304-83.

7. Feingold KR, Grunfeld C. Diabetes and Dyslipidemia. In: De Groot LJ, Chrousos G, Dungan K, et al., editors. Endotext [Internet]. South Dartmouth (MA): MDText.com, Inc.; 2000-. Available from: https://www.ncbi.nlm.nih.gov/books/NBK305900

8. Van greevenbroek MM, Schalkwijk CG, Stehouwer CD. Obesity-associated low-grade inflammation in type 2 diabetes mellitus: causes and consequences. Neth J Med. 2013;71(4):174-87.

9. Lara-Castro, C., et al., Adiponectin and the metabolic syndrome: mechanisms mediating risk for metabolic and cardiovascular disease. CurrOpinLipidol, 2007. 18(3):263-70.

10. Nora D. Volkow, Gene-Jack Wang, and Ruben D. Baler. Reward, dopamine and the control of food intake: implications for obesity. Trends Cogn Sci. 2011; 15(1): 37-46. 
Thi-Qar Medical Journal (TQMJ): Vol.(16), No.(2), 2018

Web Site: $\underline{\text { https://jmed.utq.edu.iq }}$

ISSN (Print):1992-92 18, ISSN(Online):1992-92 18

Email:utjmed@utq.edu.iq

DOI: https://doi.org/10.32792/utq/utjmed/16/2/1/

11. Volkow ND1, Wang GJ, Maynard L, et al. Dopamine is associated with eating behaviors in humans. Int J Eat Disord. 2003;33 (2):136-42.

12. Pijl, Hanno \&Romijn, Johannes. Obesity, dopamine and the metabolic syndrome: Potential of dopaminergic agents in the control of metabolism. Current Opinion in Endocrinology, Diabetes and Obesity. 2006; 13. 179-184

13. van der Zwaal EM, de Weijer BA, van de Giessen EM, et al. Striatal dopamine D2/3 receptor availability increases after long-term bariatric surgery-induced weight loss. European Neuropsychopharmacology 2016. 26 1190-1200

14. Kok P, Roelfsema F, Frolich M, et al. Activation of dopamine D2 receptors simultaneously ameliorates various metabolic features of obese women. American Journal of Physiology: Endocrinology and Metabolism 2006

15. Bahler L Verberne, HJBrakema E,et al. Bromocriptine and insulin sensitivity in lean and obese subjects. Endocr Connect. 2016; 5(6): 44-52.

16. Cincotta $\mathrm{AH}$, Meier AH, Bromocriptine (Ergoset) reduces body weight and improves glucose tolerance in obese subjects, Diabetes Care, 1996, 19, 667-670

17. Saadat N,Esmaily H, Abbasinazari $M$, et al. Does Twice-weekly Cabergoline Improve Anthropometrical and Biochemical Profiles in Prediabetes? A Randomized Double-blind Clinical Trial Pilot Study. Iran J Pharm Res. 2015; 14(Suppl): 77-86.

18. Aminorroaya A, Janghorbani M, Ramezani M, et al. Does bromocriptine improve glycemic control of obese type-2 diabetics? Horm Res. 2004; 62:55-9

19. L Bahler, H J Verberne,2 E Brakema,1 R Tepaske,3 J Booij,2 J B Hoekstra,1 and F Holleman.Bromocriptine and insulin sensitivity in lean and obese subjects. Endocr Connect. 2016 Nov; 5(6): 44-52

20. Defronzo RA. Bromocriptine: A sympatholytic, d2-dopamine agonist for the treatment of type 2 diabetes. Diabetes Care. 2011; 34:789-94

21. Kamath V, Jones CN, Yip JC, Varasteh BB, Cincotta AH, Reaven GM, et al. Effects of quickrelease form of bromocriptine (Ergoset) on fasting and postprandial plasma glucose,insulin,lipid and lipoprotein concentrations in obese nondiabetic hyperinsulinenic women. Diabetic care. 1997; 20:1697-701. [PubMed]

22. Cincotta AH, Meier AH, Cincotta JM. Bromocriptine improves glycaemic control and serum lipid profile in obese Type 2 diabetes subjects: A new approach in treatment of diabetes. Expert OpinInvestig Drugs. 1999; 8:1683-707

23. Amy R. Johnson, J. Justin Milner, and Liza Makowski.The inflammation highway: metabolism accelerates inflammatory traffic in obesity. Immunol Rev. 2012 Sep; 249(1): 218-238.

24. Shoelson SE, Lee J, Goldfine AB. Inflammation and insulin resistance. J Clin Invest. 2006; 116(8):1793-801.

25. Gustafson B. Adipose tissue, inflammation and atherosclerosis. J. Atheroscler. Thromb.2010;17:332-341

26. Krysiak R, Samborek M, Stojko R. Anti-inflammatory effects of bromocriptine in a patient with autoimmune polyglandular syndrome type 2. Neuro Endocrinol Lett. 2014;35(3):179-82. 
Thi-Qar Medical Journal (TQMJ): Vol.(16), No.(2), 2018

Web Site: $\underline{\text { https://jmed.utq.edu.iq }}$

ISSN (Print):1992-92 18, ISSN(Online):1992-92 18

Email:utjmed@utq.edu.iq

DOI: https://doi.org/10.32792/utq/utjmed/16/2/1/

27. Krysiak R1, Okopien B.Different effects of cabergoline and bromocriptine on metabolic and cardiovascular risk factors in patients with elevated prolactin levels. Basic ClinPharmacolToxicol. 2015;116(3):251-6

28. Cai D. One step from prediabetes to diabetes: hypothalamic inflammation? Endocrinology. 2012; 153(3):1010-3.

29. Hundal RS1, Petersen KF, Mayerson AB, et al. Mechanism by which high-dose aspirin improves glucose metabolism in type 2 diabetes. J Clin Invest. 2002;109(10):1321-6.

30. Goldfine AB, Silver R, Aldhahi W, et al. Use of salsalate to target inflammation in the treatment of insulin resistance and type 2 diabetes. ClinTransl Sci. 2008 May;1(1):36-43.

\section{تأثير البروموكريتين على القياسات الأنثرويومترية والايض و الالتهاب في النساءالبدينات}

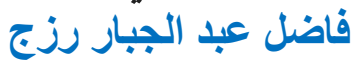
مجموعتين المجموعة الأولى: مجموعة السيطرة (N = 16)، نصحت هذه المجمو عة فقط للعلاج الغذائي

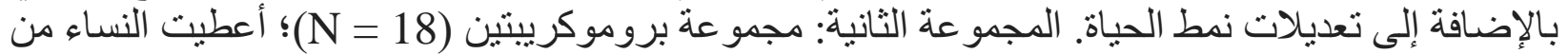

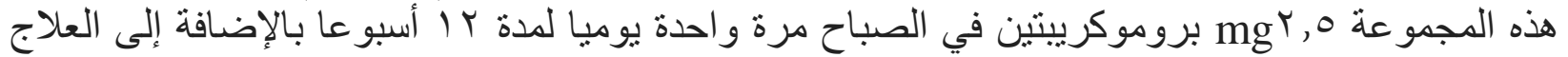

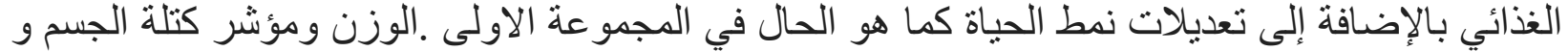

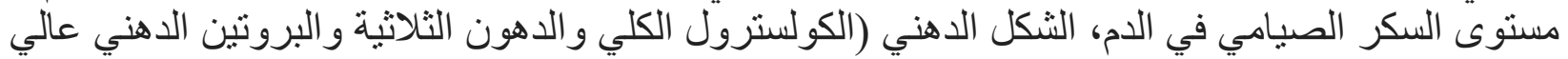
الكثافة والبروتين الدهني منخفض الكثافة)وعلامات الالتهابات عالية الحساسية للبروتين التفاعلي و و عامل نخر الورم تم قياس ألفا (hsCRP)C النتائج: مقارنة مع قيمة خط الأساس، انخفض الوزن ومؤشر كتلة الجسم بشكل كبير على كلى كل من بروموكريبتين ومجمو عة السيطرة ولكن التغيير في الوزن ومؤشر كتلة الجسم لم تختلف اختيلافئا كبير ا بين

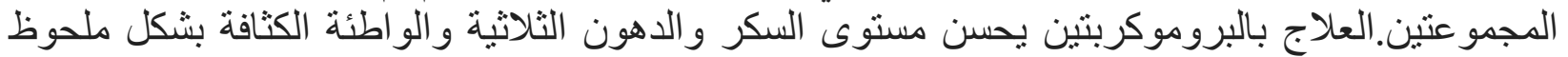

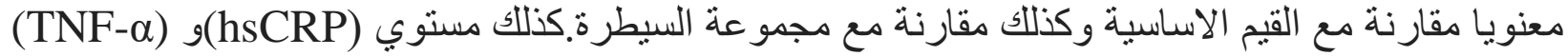

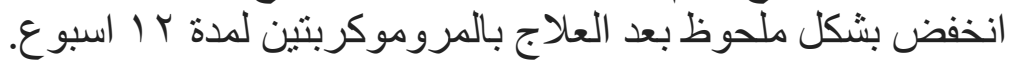
الاستتتاج: البروموكربتين يقلل السكر الصيامي ويحسن مستوى الدهون ويثبط الالتهاب بشكل فعال في النساء السمينات. التوصيات: نوصي بدراسات سريرية اخرى على عدد اكثر وفترة اطول لاستكثاف تأثير البروموكربتين على النساء البدينات 